\title{
砂地盤における重錘落下締固め工法に関する室内模型実験 LABORATORY MODEL TESTS ON DYNAMIC CONSOLIDATION METHOD IN SAND
}

\author{
下平祐司*, 山肩邦男**, 伊藤 淳 志***, 無津呂 大輔**** \\ Yuuji SHIMOHIRA, Kunio YAMAGATA, Atsushi ITO \\ and Daisuke MUTSURO
}

Laboratory model tests on Dynamic Consolidation Method in a loose sand was carried out to investigate the impact load - settlement characteristics. The main conclusions are summarized as follows.

(1) The dynamic settlement characteristics of the ground are shown in the impact load-settlement curve.

(2) The maximum impact load is proportional to the impact velocity at the first blow. But when blow is repeated, the maximum impact load increases in spite of a fixed impact velocity.

(3) The maximum impact load is equivalent to the maximum pre-load in the static loading test.

(4) The soil improvement effect is governed by the maximum impact load and the number of blows.

keywords : soil improvement, tamping, sand, model test, load-settlement curve 地盤改良, 締固め, 砂, 模型実験, 荷重〜沈下量曲線

\section{1. 序}

軟弱な粗粒土地盤に対する地盤改良工法の一つに, 重 量数 $10 \mathrm{tf}$ の重錘を数 $10 \mathrm{~m}$ の高さから繰り返し自由落下さ せることにより地盤を締固める重錘落下締固め工法があ る. 筆者らは，同工法に関する現場実験における地盤 の締固め変形状況の観察結果に基づいて, 重鍾落下時 の地盤内最大応力分布の解析法を提案し, 現場実測值と の比較検討を行った ${ }^{1}$ )。この解析法は, (衝撃荷重の最 大值） $=$ (静的極限支持力）という仮定の下で提案した ものであるが，重鍾落下締固め工法が対象とするよう なゆるい砂質系地盤における動的支持力と静的支持力の 比較検討を行った事例はみあたらない。また，重鏵落下 時の衝撃荷重については, 衝撃荷重の経時変化に関す る検討は文献 ${ }^{2)}$ などに報告されているが，衝撃荷重〜 貫入量関係について検討された事例はみあたらない.

以上のことから, 重錘落下締固め工法の締固め変形機 構を解明するには, 衝撃荷重〜貫入量関係の特性を把握 することが重要と考え, 室内模型実験を実施した ${ }^{3 i \sim 5)}$.
実験には，一様なゆるい湿潤砂地盤を作製できる実験士 槽を用い，衝撃荷重と貫入量を動的に計測する重鏵落下 実験ならびに平板載荷試験を実施することとした。本 報では，これらの室内模型実験の結果を報告し，衝撃荷 重〜貫入量関係の特性, 衝撃荷重と静的支持力之の比較 検討および締固め範囲の比較検討を行う. 同様の研究 として，大島ら ${ }^{61 \sim 8)} は ，$ 室内実験および現場実験にお ける衝撃荷重の測定を試みているが，検討対象が地表面 の 1 打撃目のみに限られていること，重錘の貫入量を 計測していないこと, 静的載荷試験を実施していないこ となどが本報の実験と異なる。

なお，本論文の内容は，文献 5 ）で中間報告したもの に，一部の加筆や修正を行ったものであることをお断り しておく.

\section{2. 実験概要}

（1）実験土槽および実験地盤
*日本建築総合試験所 研究員・工修

** 関西大学工学部建築学科 教授. 工博

*** 関西大学工学部建築学科 専任講師 $\cdot$ 工博

**** 東急建設 工修
Research Engineer, General Building Research Corp., M. Eng.

Prof., Dept. of Architecture, Faculty of Engineering, Kansai Univ., Dr. Eng.

Lecturer, Dept. of Architecture, Faculty of Engineering, Kansai Univ., Dr. Eng.

Tokyu Construction Corp., M. Eng. 
本研究で使用した実験土槽は, 図- 1 に示す内径 $1480 \mathrm{~mm}$, 高さ $1800 \mathrm{~mm}$ の鋼製容器のものである ${ }^{91}$. 実 験地盤の作製は，下部に設けた送排水口から圧力水を送 水することによって一旦砂をボイリングさせ，その後 3 時間自然排水するという方法によった。この方法によっ て作製した実験地盤の諸元および砂試料（腚川産の川砂） の諸元を表 -1 および図ー 2 に示す. 図一 2 に示すよ うに, 表層部の数 $\mathrm{mm}$ はボイリングの影響で粒度が細か くなっているが，表層部以媣については粒度分布にほと んど差は認められない.

作製した実験地盤の強度性状を把握するため，図ー3 に示すステンレス製のコーンを $5 \mathrm{~mm} / \mathrm{sec}$ の速度で梁度 $96 \mathrm{~cm}$ まで貫入させ，コーン貫入抵抗 $q_{c}$ を深度 $1 \mathrm{~cm}$ ごと に測定した，コーンの貫入位置は，図ー4に示すように 実験土槽中心から $6 \mathrm{~cm} （=0.5 D, D:$ 後述の重鍾および 平板の直径）ピッチで計 21 点である. $q_{\mathrm{c}}$ 〜深度 $\mathrm{z}$ 曲線群 を図一 5 に， $q_{\mathrm{c}}$ の分布図（等 $q_{\mathrm{c}}$ 線図）を図一 6 に示す。 $q_{\mathrm{c}}$ は深度方向に一様に漸増しているが，水平方向にはほ ぼ均等とみなしてよかろう。

（2）載荷装置および載荷方法

重鍾落下装置を図一 7 に示す。重鍾は，直径 $D=120 \mathrm{~mm}$, 高さ $80 \mathrm{~mm}$ の鋼製で, その底面は粗な表面 になるように深さ約 $1 \mathrm{~mm}$, ピッチ約 $1.4 \mathrm{~mm}$ の同心円状 の溝が刻んである. カイイドロッドは, 重錘底面が傾斜し て打撃するのを防ぐとともに，非接触レーザー式変位計 用のターゲットを取り付けるためのものであり，重鍾 と一体となって落下する，衝撃荷重 $P_{\mathrm{d}}$ は，重錘上面に垂 直に貼付した加速度計（容量： $\pm 100 \mathrm{~g}$, 固有振動数 : $2 \mathrm{kHz})$ の測定值を用いて以下の(1)式から求めた.

$$
P_{\mathrm{d}}=\mathrm{m} \alpha(t)
$$

ここに， $m$ ：重鍾部の質量 $=10 \mathrm{~kg}$ (重鍾，ガイドロッド， ターゲットおよびハンドルの質量の合計） $\alpha(t):$ 加速度の測定值（単位 : $g$, 静止時を $0 \mathrm{~g}$ とする)

なお，図一７におけるガイドロッドとボールベアリング との間の摩擦などによるエネルギーロスについては, 後 述の(2)式による衝突速度と $\alpha(t)$ を積分して求めた衝突 速度との差が最大 $5 \%$ であったことから，無視しうるも

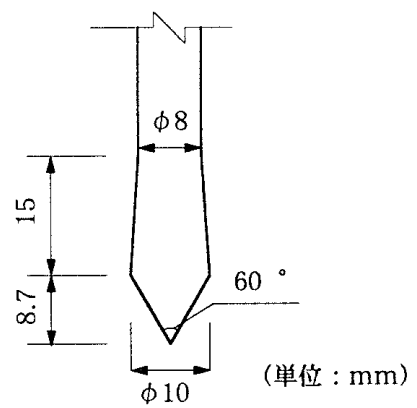

図-3 コーンの先端形状
表 -1 実験地盤の諸元

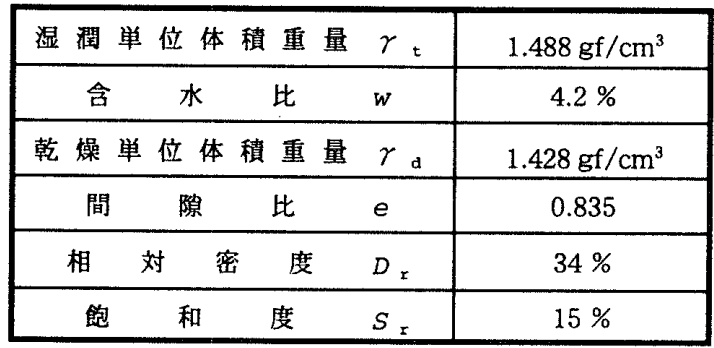

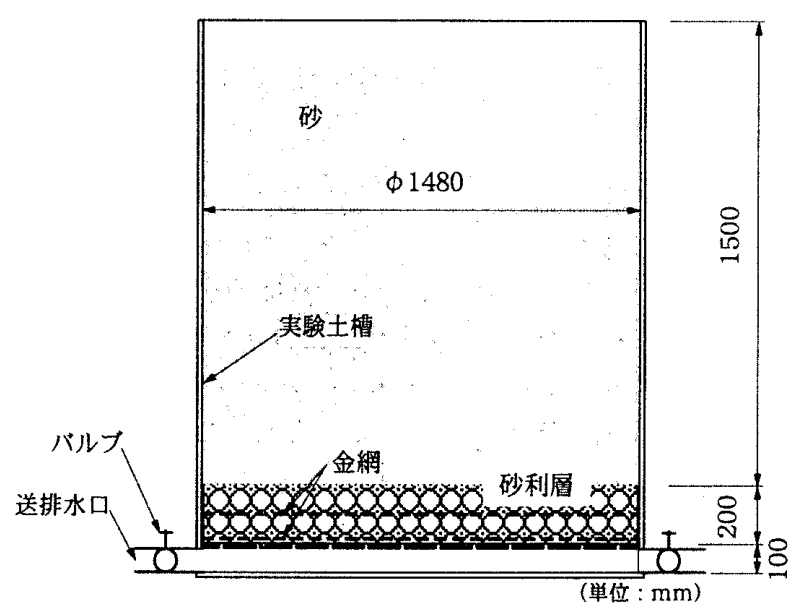

図-1 実験土槽

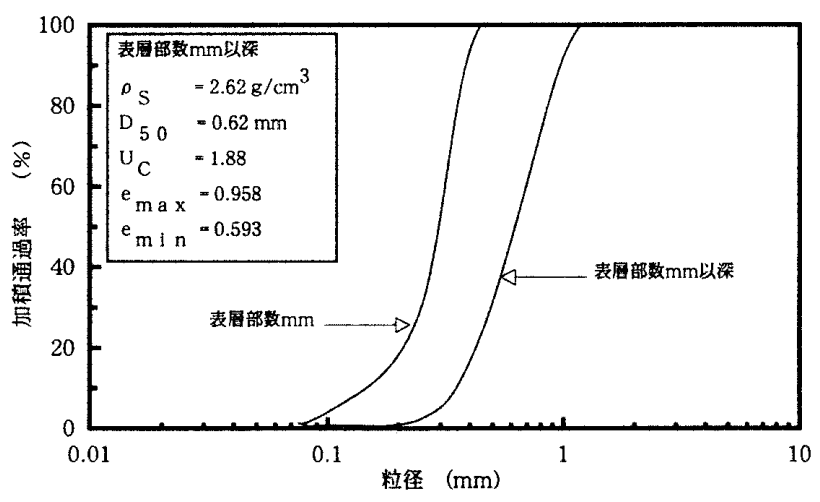

図 -2 砂試料の諸元

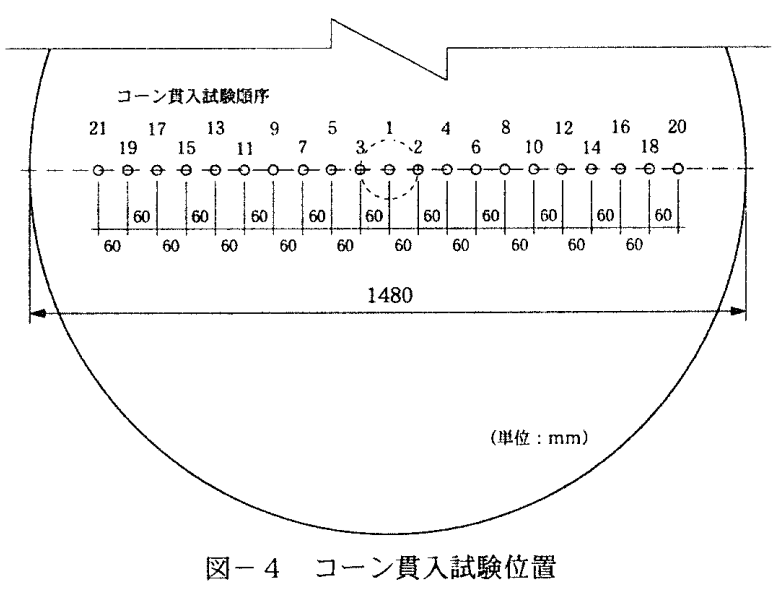


のと判断した。 また，重錘の貫入量は，ガイドロッドに 固定したターゲットの動きを非接触レーザー式変位計

（容量 : $80 \mathrm{~mm}$, 精度 : $0.18 \mathrm{~mm}$ ）により測定した. 重

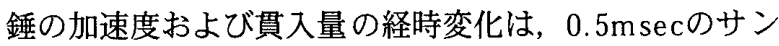
プリング間隔で $100 \mathrm{~Hz}$ のローパスフィルターを施して 記録した。

平板載荷装置を図ー 8 に示す，平板載荷試験に使用し た円形平板は, 直径 $D=120 \mathrm{~mm}$, 厚さ $19 \mathrm{~mm}$ のステンレ 又鋼製であり，平板の底面には，先述の重鏵底面と同様 な溝を刻んでいる，載荷荷重および貫入量は，載荷用ロッ ド上部のロードセル（容量 : $2 \mathrm{tf}$ ，精度 : $0.5 \mathrm{kgf}$ ）およ び載荷用ロッドに固定したターゲットの動きを 2 本の変 位計（容量： $100 \mathrm{~mm}$, 精度 : $0.05 \mathrm{~mm}$ ）により計測し た. 平板載荷試験は，1段階 $35 \mathrm{kgf}$ の荷重制御による多 サイクル方式で行い，重鍾落下実験の場合と同様に貫入 量が所定の目標貫入量を越えるまで載荷することとした. 荷重の保持時間は, 処女荷重階で5分間, 履歴荷重階で 1分間とした。

なお，各実験終了後は，重鍾あるいは平板を取り除い た後に(2)に示した要領でコーン貫入試験を実施した.

\section{(3) 実験種類}

重錘の落下高さとしては，実験開始時の地表面を基準 G.LとしてのG. $\mathrm{L}+25 \mathrm{~cm}$ およびG. $\mathrm{L}+50 \mathrm{~cm}$ ，一打撃ごと に染くなる打搫孔底を基準として，これより $+25 \mathrm{~cm}$ お よび $+50 \mathrm{~cm}$ とする計 4 種類を設定した，重鍾の落下高 さがG.L.+25cmおよびG.L.+50 cmの場合は，打撃を繰り 返して重鍾の貫入が進むにつれて衝突面までの落下高さ が増大するのに対し，重鍾の落下高さが打撃孔底 $+25 \mathrm{~cm}$ おび打撃孔底 $+50 \mathrm{~cm}$ の場合は, 全打撃を通じ て衝突面までの落下高さは一定となる. また，それぞれ の落下高さに対して全貫入量の目標を $1 D, 1.5 D$ よび $2 D(D=12 \mathrm{~cm})$ と設定した。この全貫入量の目標は， 実際の重鍾落下締固め工法の現場施工における重錘の全 貫入量が $(1 \sim 2) D$ 程度であることを考慮して設定したも のである.

実験種類としては，表一 2 に示すように，上述の重鍾 の落下高さおよび目標貫入量を組み合わせた 12 種類 （No. $1 \sim 12 ）$ に加え，目標貫入量を $1 D ， 1.5 D$ おび $2 D$ とした平板載荷試験 3 種類（No.13〜15），重鍾を $1 D$ まで打撃貫入させ，生じた打撃孔底において実施し た平板載荷試験 2 種類（No.16，17）の計17 種類である.

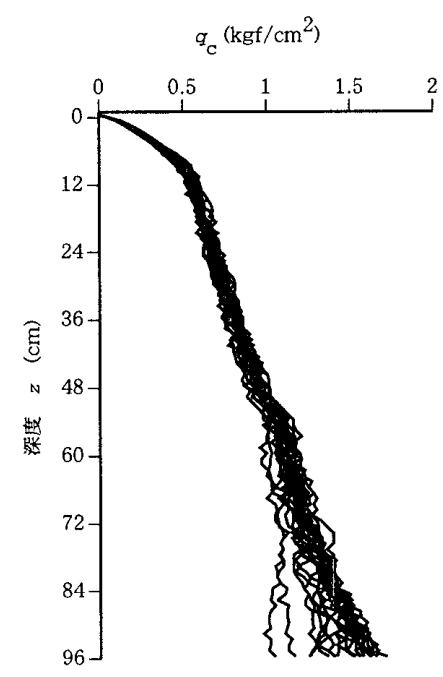

図- $5 \quad q_{C} \sim Z$ 曲線群

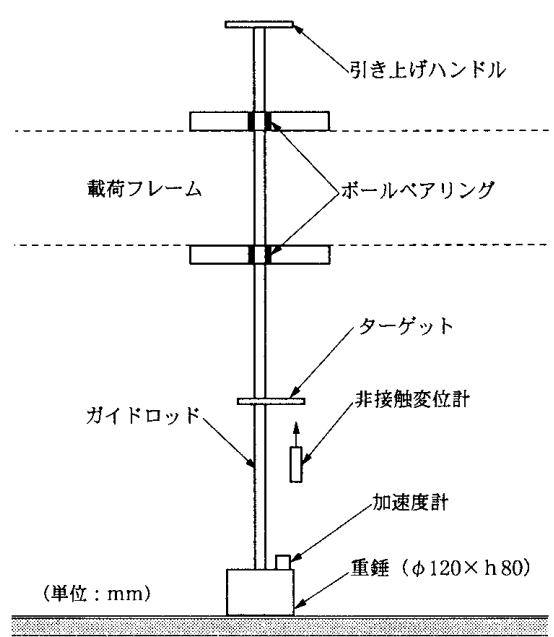

図 -7 重鍾落下実験装置図

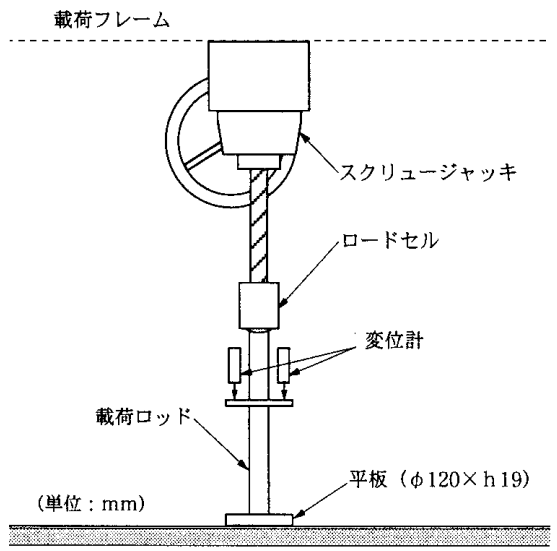

図 -8 平板載荷試験装置図

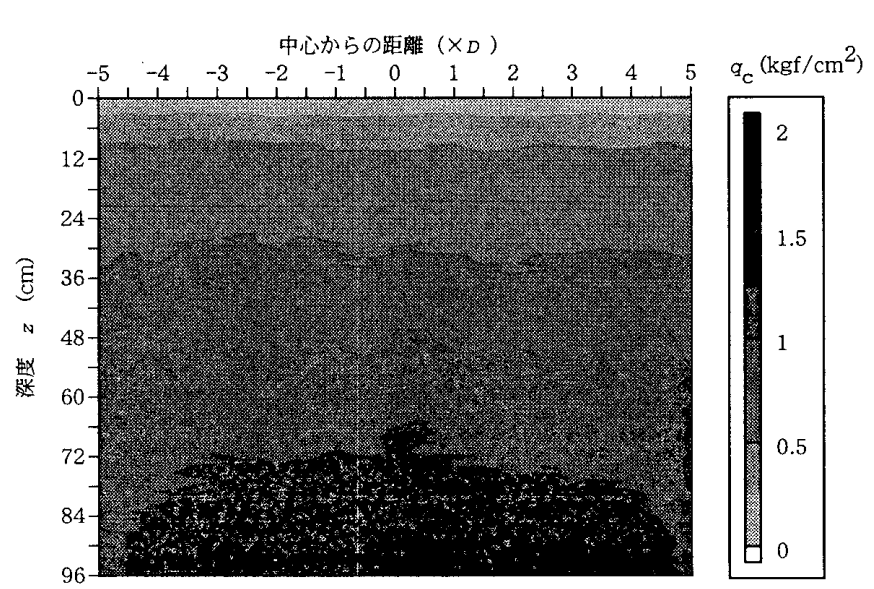

図-6 $\quad q_{C}$ の分布図

\begin{tabular}{|c|c|c|c|c|c|c|}
\hline \multirow[t]{2}{*}{ 実鸰№. } & \multirow{2}{*}{ 載荷方法 } & \multirow{2}{*}{ 重鍾落下高さ } & \multirow{2}{*}{ 目標貫入量 } & \multirow{2}{*}{$\begin{array}{c}\text { 打慗回数 } \\
n \text { (回) }\end{array}$} & \multicolumn{2}{|c|}{ 実測買入显 } \\
\hline & & & & & (cm) & $\left(\times_{D}\right)$ \\
\hline 1 & \multirow{12}{*}{ 重锤落下 } & \multirow{3}{*}{ G.L. $+50 \mathrm{~cm}$} & $1 D$ & 3 & 14.6 & 1.22 \\
\hline 2 & & & $1.5 \mathrm{D}$ & 5 & 19.5 & 1.63 \\
\hline 3. & & & $2 D$ & 8 & 26.9 & 2.24 \\
\hline 4 & & \multirow{3}{*}{ 打慗孔底 $+50 \mathrm{~cm}$} & $1 D$ & 3 & 13.9 & 1.16 \\
\hline 5 & & & $1.5 D$ & 6 & 19.2 & 1.60 \\
\hline 6 & & & $2 D$ & 9 & 26.4 & 2.20 \\
\hline 7 & & \multirow{3}{*}{ G.L. $+25 \mathrm{~cm}$} & $1 D$ & 5 & 13.4 & 1.12 \\
\hline 8 & & & $1.5 \mathrm{D}$ & 8 & 19.1 & 1.59 \\
\hline 9 & & & $2 D$ & 13 & 27.0 & 2.25 \\
\hline 10 & & \multirow{3}{*}{ 打擊孔底 $+25 \mathrm{~cm}$} & $1 D$ & 6 & 12.5 & 1.04 \\
\hline 11 & & & $1.5 \mathrm{D}$ & 13 & 19.6 & 1.63 \\
\hline 12 & & & $2 D$ & 20 & 26.7 & 2.23 \\
\hline 13 & \multirow{3}{*}{ 平板瀻荷 } & & $1 D$ & & 12.3 & 1.03 \\
\hline 14 & & $\square$ & $1.5 \mathrm{D}$ & & 19.7 & 1.64 \\
\hline 15 & & & $2 D$ & & 24.5 & 2.04 \\
\hline 16 & \multirow{2}{*}{$\begin{array}{l}\text { 重錘落下 } \rightarrow \\
\text { 平板载荷 }\end{array}$} & G.L. $+50 \mathrm{~cm}$ & \multirow{2}{*}{$\begin{array}{cc}1 D & \text { (重鍾) } \\
2 D & \text { (平板) } \\
\end{array}$} & 3 & $12.8 \rightarrow 26.2$ & $1.07 \rightarrow 2.18$ \\
\hline 17 & & G.L. $+25 \mathrm{~cm}$ & & 5 & $12.6 \rightarrow 24.4$ & $1.05 \rightarrow 2.03$ \\
\hline
\end{tabular}




\section{3．衝撃荷重～貫入量関係の特性}

図－9には，重鍾落下実験（No. 1 １2）における打 撃回数 $n$ と貫入量 $s$ との関係を示した. ただし， $n$ は平 方根目盛上にプロットした. 文献 ${ }^{101}$ の遠心模型実験の 場合と同様に, $\sqrt{n} \sim s$ 関係には直線関係が認められる. また，落下高さの設定が同一の場合の $\sqrt{n} \sim_{s}$ 関係はほ ぼ重なっており，実験地盤の再現性が確認できる.

図-10には，目標貫入量2Dの場合の重鍾落下実験

（№. 3，6，9，12）における重鉷の衝突速度 $v_{0}$ と衝 撃荷重の最大値 $P_{\mathrm{d} \max }$ との関係を示した．ここで， $v_{\mathrm{o}}$ は 次式によって求めた.

$$
v_{0}=\sqrt{2 g H}
$$

ここに, $g:$ 重力加速度 $\left(=980 \mathrm{~cm} / \mathrm{sec}^{2}\right)$

$H$ : 衝突面までの落下高さ $(\mathrm{cm}$, 重鍾落下高 さがG. L + $50 \mathrm{~cm}$ およびG. L $+25 \mathrm{~cm}$ の場合 は 1 打擊前までの実測全貫入量を所定落

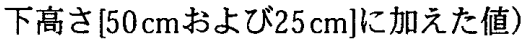

同図より，(1)地表面における 1 打撃目については，大 島ら ${ }^{2)}$ が示したように $P_{\text {dmax }}$ と $v_{0}$ の関係は原点を通る比 例関係（図中の実線）にあること，(2)打撃を繰り返した 場合は，V。（H）が一定の場合（実験No. 6 およびNo.12） でも $P_{\mathrm{dmax}}$ は次第に増大すること，(3)最終打撃時におい て，深度およびV。（H）がほぼ相等しい実駼No. 6 （落 下高さ : 孔底 $\left.+50 \mathrm{~cm}, v_{0}=313 \mathrm{~cm} / \mathrm{sec}, z=24.5 \mathrm{~cm}\right)$ と 実験No. 9 (落下高さ：G.L $+25 \mathrm{~cm}, \quad v_{0}=314 \mathrm{~cm} / \mathrm{sec}$ ， $z=25.3 \mathrm{~cm})$ では， $P_{\mathrm{dmax}}$ はほぼ同等であることなどが 指摘できる.

図-11には，目標貫入量2Dの場合の重鍾落下実験 （No. 3，6，9，12）における1打撃ごとの衝撃荷重 $P_{\mathrm{d}}$ (加速度からの換算值) および貫入量 $s$ の経時変化に ついて，代表的な打撃回数を選んで重ね合わせて示した. 同図より，以下のことが指摘できる. (1)打撃回数が増加 するにしたがって， $P_{\mathrm{a}}$ の作用時問が短くなり， $P_{\mathrm{a}}$ の最 大值 $P_{\mathrm{d} \max }$ が大きくなる. (2) $P_{\mathrm{d}}$ は $P_{\mathrm{d} \max }$ に達した後一旦

No.3 落下商さ: G.L. $+50 \mathrm{~cm}$ No,6 落下商さ：芤底 $+50 \mathrm{~cm}$
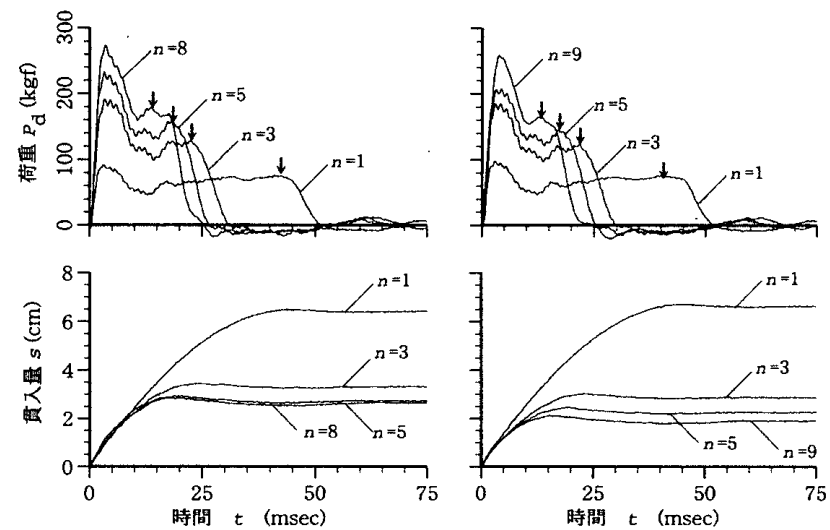

減少するが，その後再び增大し小さなピーク値（図 -11中の $\downarrow$, 以下”第 2 ピーク值”と称する）を示し ている. (3)第2 ピーク值は, 初期の打撃ほど明膫に現れ ており，その発生時間は，sが最大となる時間とほぼ一

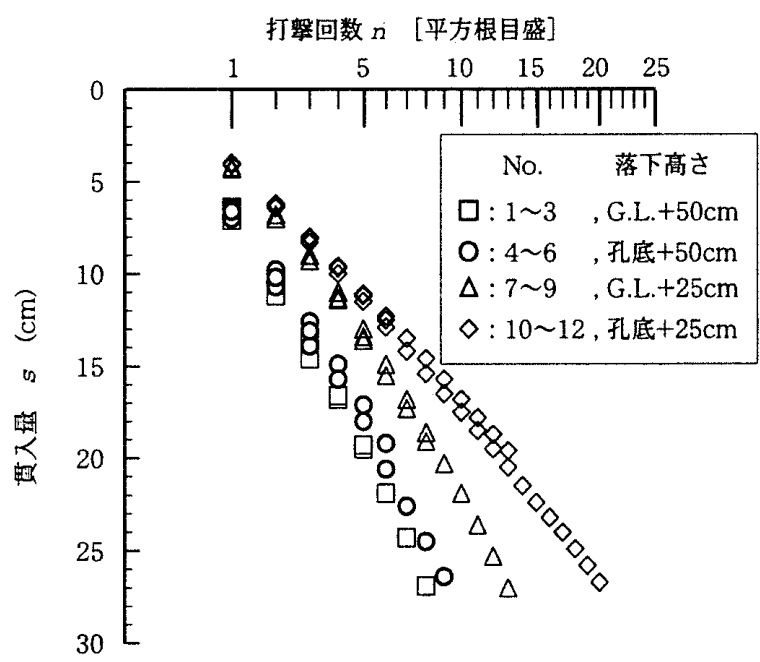

図-9 $\sqrt{n} \sim s$ 関倸図

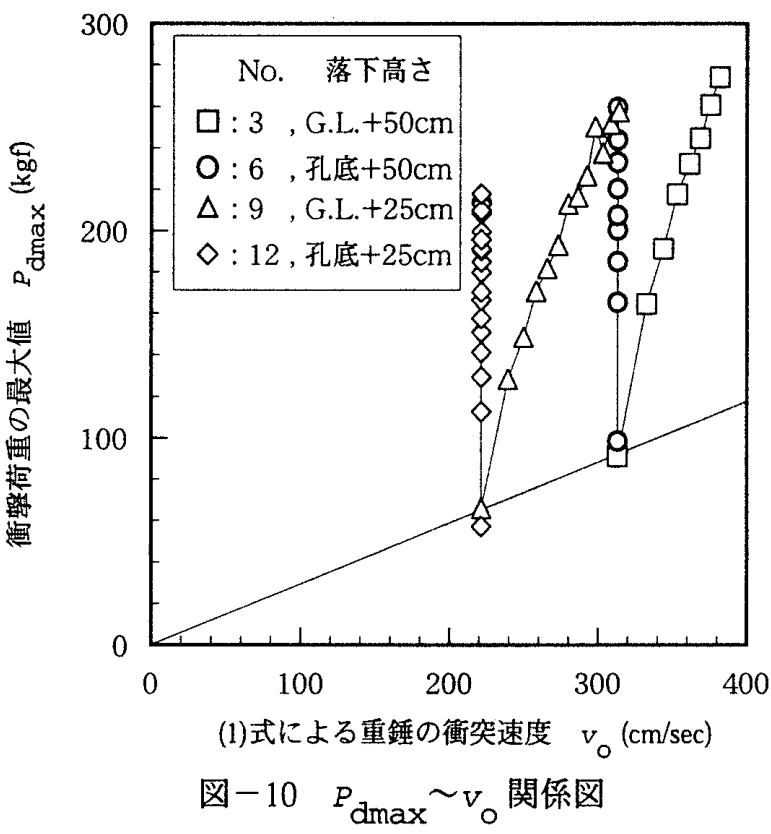

No.9 落下高さ : G.L. $+25 \mathrm{~cm}$ No.12 落下高さ：孔坻 $+25 \mathrm{~cm}$
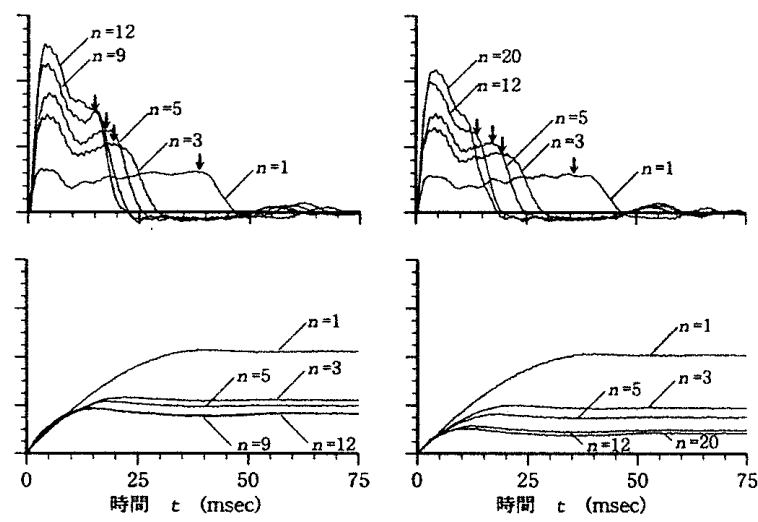

図-11 $P_{\mathrm{d}}, s \sim t$ 関係図 
致している. (4)打撃回数が増加するにしたがって，sの 最大值の発生時間が早くなり，かつ，リバウンドが大き くなる.

図- 12 には，目標貫入量 $2 D$ の場合の重鍾落下実験 （№. 3，6，9，12）における衝撃荷重 $P_{\mathrm{d}}$ と貫入量 $S$ との関係を示した. 1 打撃ごとの $P_{\mathrm{d}} \sim s$ 関係についてみ ると， $P_{\mathrm{d}}$ は比較的小さな $s$ で $P_{\mathrm{dmax}}$ を示して一旦減少す るが，その後再びsとともに増加する傾向にあり，この 傾向は初期の打撃ほど明膫に現れている. また，全体の $P_{\mathrm{d}} \sim s$ 関係についてみると, 各打撃時の $P_{\mathrm{a} \max }$ を包絡す る $P_{\mathrm{dmax}} \sim s$ 曲線と $P_{\mathrm{dmax}}$ 以後に現れる $P_{\mathrm{a}} \sim s$ 曲線の 2 曲 線が存在するようにみれる. 前者の $P_{\mathrm{dmax}} \sim s$ 曲線は, 重鍾の慣性力に対する地盤反力が, 後者の $P_{\mathrm{d}} \sim S$ 曲線は, 衝撃力による地盤のゆりこみ沈下伟）（10)に起因する地 盤反力の增加傾向が現れたものと考えられる．この地盤 のゆりこみ沈下に起因する地盤反力の增加傾向は， 1 打 撃あたりの打撃エネルギーが大きいもの（衝突面まで の落下高さが大きいもの）ほど明膫に現れていることが わかる。

図ー13には，図ー12に示した 4 本の $P_{\mathrm{d}} \sim s$ 関係曲線 を重ねて示した，同図より，(1)ゆりこみ沈下に起因する 地盤反力の増加傾向（図中の網掛计部分）は，重鍾の落
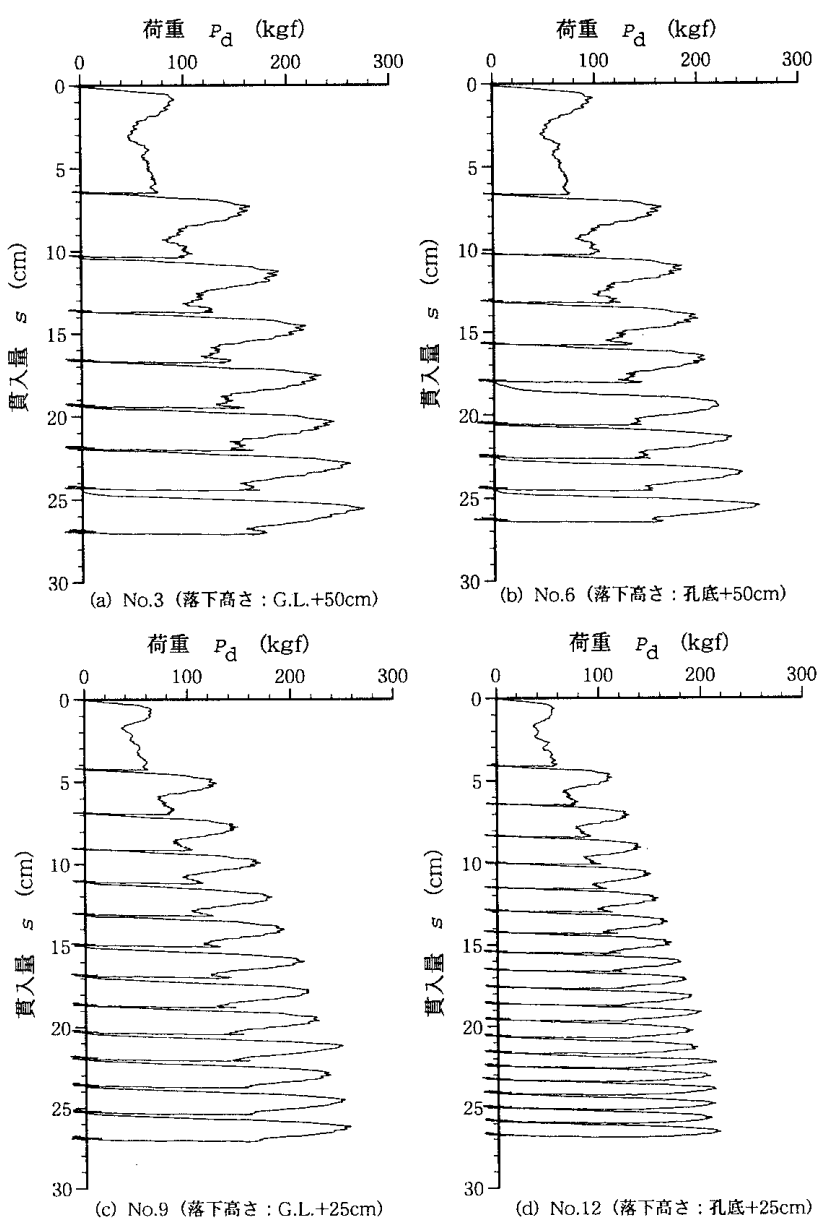

図 $-12 \quad P_{\mathrm{d}} \sim S$ 関係図
下高さによらずほぼ同様であり, 地盤の種類および状態 （密度，含水比など）により一義的に決まるものと考 えられること, (2)重鍾の 1 打あたりの貫入量は, 打撃が 繰り返されるにしたがって次第に隇少していることなど がわかる.

以上の図-11〜13の傾向から, 重錘落下時の衝撃荷 重と貫入量の関係は以下のようであると推察される. 打 撃の初期においては, 衝撃に伴う地盤のゆりこみ沈下 が生じやすいため, 衝撃荷重の作用時間が長く, また, 地盤のゆりこみ沈下が収斂した時点における地盤反力が ピーク值として比較的明瞭に現れる. 打撃を繰り返す と, 地盤が締まってくるため, 衝撃荷重の最大値は次第 に大きくなり，かつ，貫入量のリバウンドが大きくなつ てくる.また，ゆりこみ沈下が生じにくくなるため， 衝撃荷重の作用時間が短くなり，第 2 ピーク值が明膫に 現れないようになる.なお，比較的密な地盤において は, $P_{\mathrm{d}} \sim S$ 関倸曲線における上述のゆりこみ沈下の特性 を現す部分が減少することを，筆者ら ${ }^{4}$ は確認している.

\section{4. 衝撃荷重と静的支持力との比較}

図一 14 には, 目標貫入量 $2 D$ の場合の平板載荷試験 (No.15）の荷重 $P_{\mathrm{s}} \sim$ 沈下量 $s$ 曲線（包絡線）ならびに, 重鍾落下実験（No. 3，6，9，12）另得た衝撃荷重 の最大值 $P_{\mathrm{dmax}}$ 〜貫入量 $s$ 関係を重ねて示した。ここで,

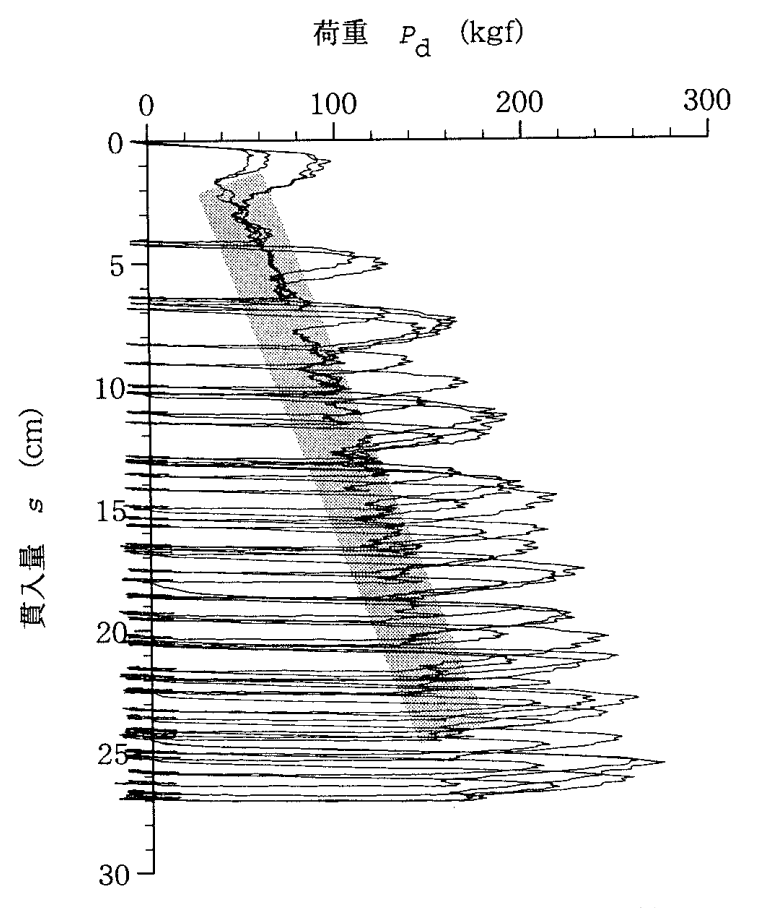

図-13 $\quad P_{\mathrm{d}} \sim S$ 関係図（一覧）

注) 振動や衝撃によって砂の粒状構造が一時的に破嗯して間 隙比が減少し, より密な粒状構造が再編成されることに起 因する沈下 
重鏵落下実験における貫入量としては，図ー12におけ る各打撃時の $P_{\mathrm{dmax}}$ に対応する全貫入量を採用している. 落下高さの影響については, 打撃孔底 $+25 \mathrm{~cm}$ の場合が 他の場合と較べて同一貫入量に対する荷重が小さいが, 他の落下高さの場合はあまり大きな差は認められない。

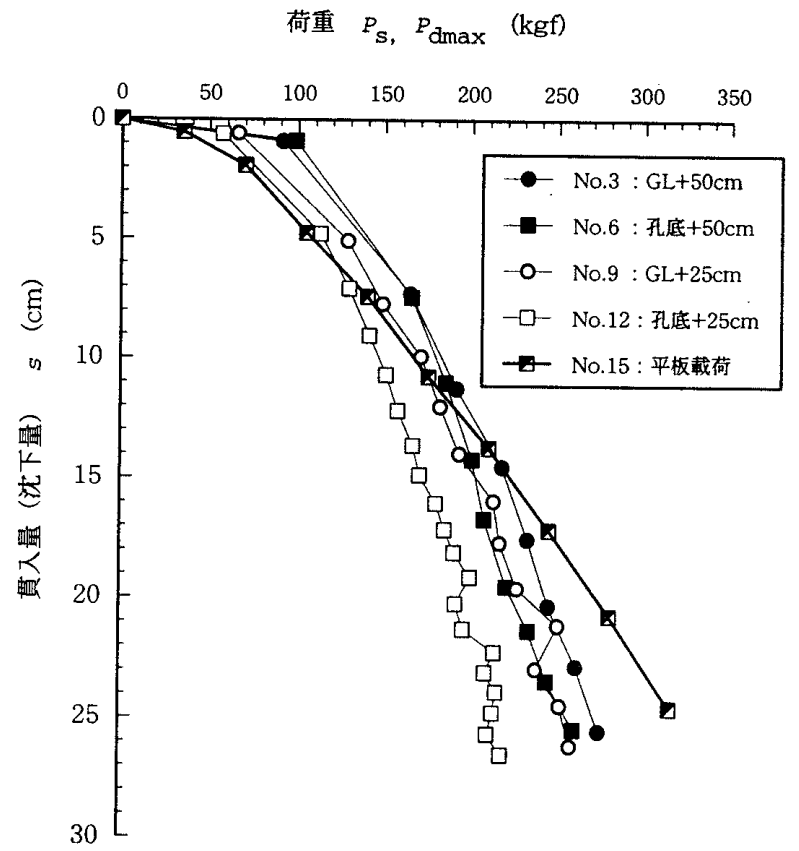

また, 平板載荷試験の $P_{\mathrm{s}} \sim s$ 関係と比較すると, $s か ゙ 1 D$ 程度までは重鍾落下実験の衝撃荷重の最大值が平板載荷 試験の荷重を上廻るが，sが1D以上の範囲では衝撃荷重 の最大值が若干下廻っており，両者の大小関係は貫入量 により異なる.

図一 15 には，目標貫入量 $2 D$ の場合の重鍾落下実験 (No. 3，6，9，12）および平板載荷試験（№.15） 終了後に行った地表面沈下量の測定結果を示した，測定 值が小さくバラツキが大きいが，いずれの場合も周辺地 盤は沈下している．図一14の $P_{\mathrm{d}} ， P_{\mathrm{s}} \sim s$ 曲線において 明瞭な極限荷重が現れていないこと，図ー15において 全般せん断破壊型の特徵である周辺地盤の隆起が生じて いないこと, 後述の図一18における周辺地盤の締固め 範囲の分布形から判断すると, 本実験の範囲では, 载荷 方法にかかわらずパンチングせん断破壊型で地盤が破壊 したものと考えられる.

図ー16には，重鍾を1Dまで打撃貫入させ，生じた打 撃孔底において平板載荷試験を実施した場合（実験 №.16，17）の $P_{\mathrm{d}}, P_{\mathrm{s}} \sim s$ 関係を示した. また, 図 -17 には，両実験における平板載荷試験での荷重 $P_{\mathrm{s}} \sim$ 残留沈下量 $S_{R}$, 弾性戻り量 $S_{\mathrm{E}}$ 関係を示した。図一16お よび図一 17 中には，最終打撃時の $P_{\mathrm{dmax}}$ をよで併記して いるが， $S_{R}$ は付近から增大しはじめる傾向にあるこ

図-14 $P_{\mathrm{S}}, P_{\mathrm{dmax}} \sim \mathrm{s}$ 関倸図

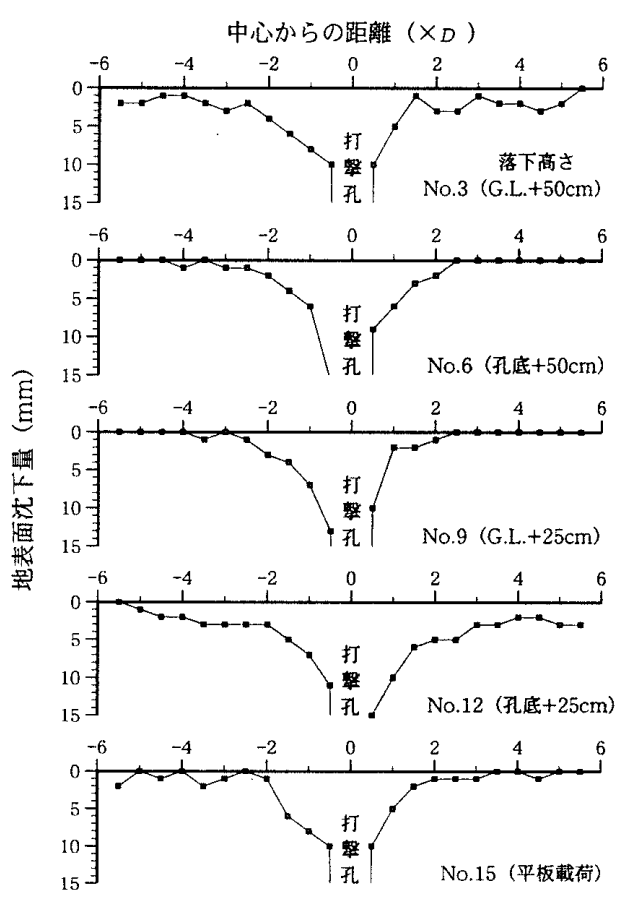

図-15 地表面沈下量の分布図

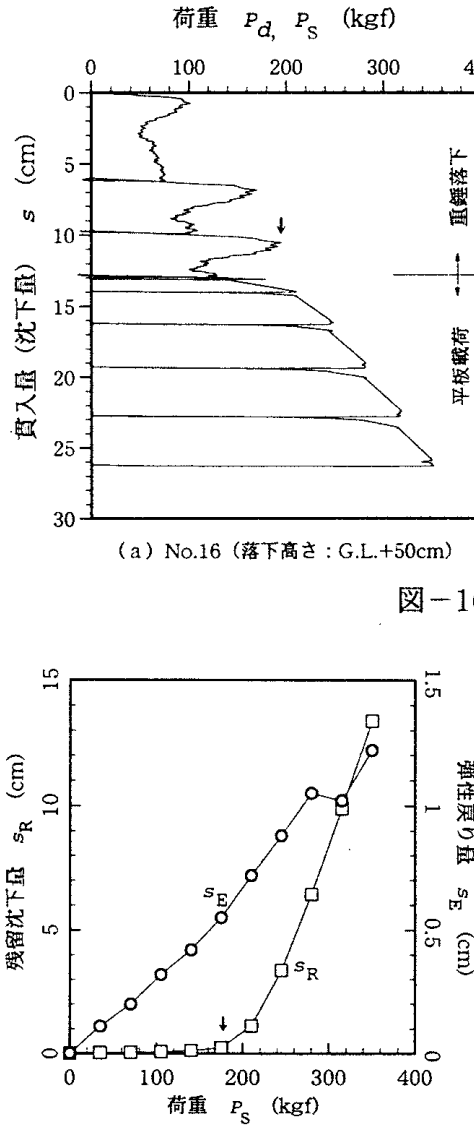

(a) No.16 (落下高さ: G.L. $+50 \mathrm{~cm}$ )

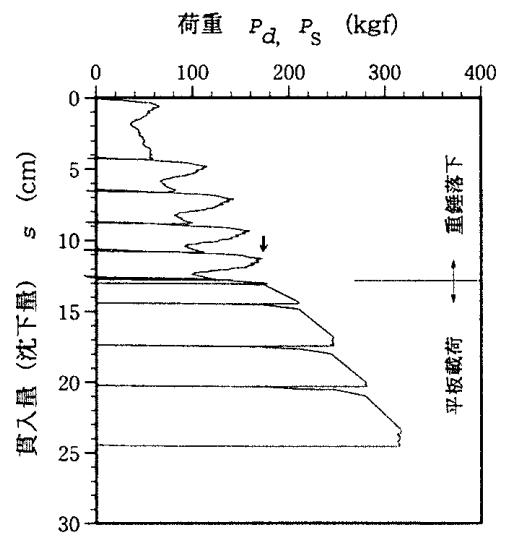

(b) No.17 (落下高さ: G.L. $+25 \mathrm{~cm}$ )

-16 $P_{d}, P_{\mathrm{S}} \sim \mathrm{s}$ 関係図

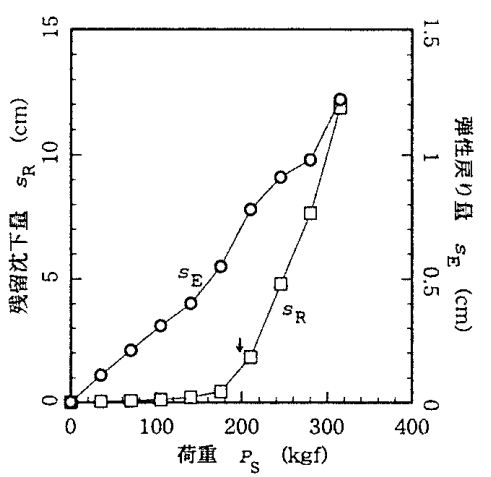

(b) No.17 (落下高さ: G.L. $+25 \mathrm{~cm}$ )

図-17 $s_{R}, \quad s_{E} \sim P_{S}$ 関係図 
と， $s_{\approx}$ も付近からわずかながら増大していることが 読みとれる。この例から考えて, 重鍾落下による衝撃荷 重の最大值は, 静的な載荷における履歴最大荷重に相 当するとみてよかろう。

\section{5. 締固め効果の比較}

図ー18には，各実験終了後に行ったコーン貫入試験 により得られた $q_{\mathrm{c}}$ から， $q_{\mathrm{c}}$ の初期值原地盤での測定値, 図一6)を減じて得られた増分 $d q_{c}$ を， $q_{c}$ の初期值で除 して得られた $q_{c}$ の增大率 $I_{\mathrm{dqc}}$ の分布図を示した．同図 より，締固め範囲の分布は，文献1) で仮定したように，
貫入目標 $1 D$

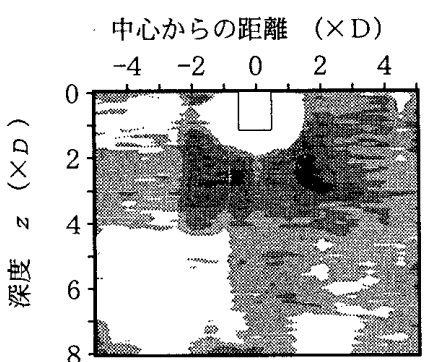

(a) No.1 $(n=3)$

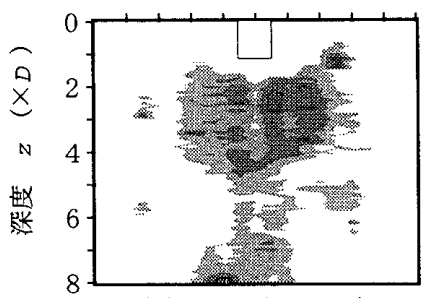

(d) No.4 $(n=3)$

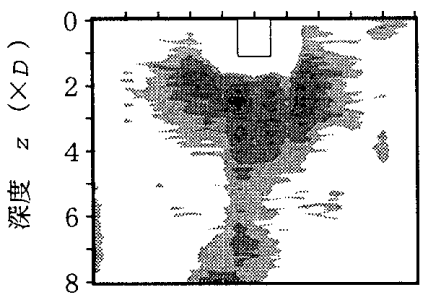

(g) No.7 $(n=5)$

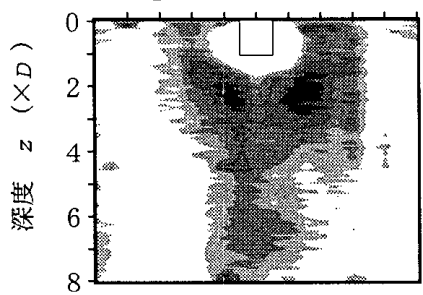

(j) No.10 $(n=6)$

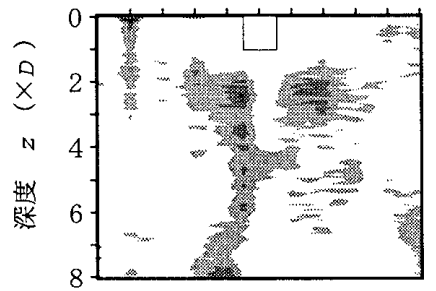

(m) No.13

註) $n:$ 打撃回数
貫入目標 $1.5 D$

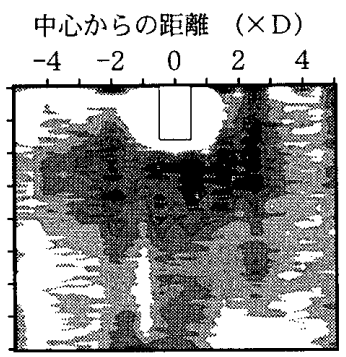

(b) No.2 $(n=5)$

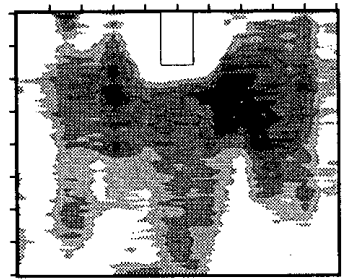

(e) No.5 $(n=6)$

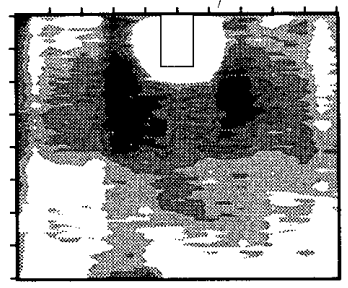

(h) No.8 $(n=8)$

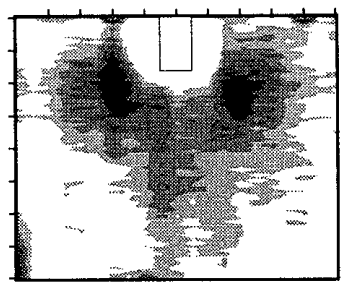

(k) No.11 $(n=13)$

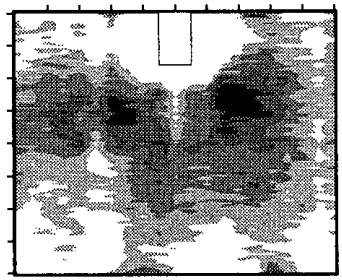

(n) No.14
重鍾落下

落下高さ:G.L. $+50 \mathrm{~cm}$

重鍾落下

落下高さ:孔底 $+50 \mathrm{~cm}$

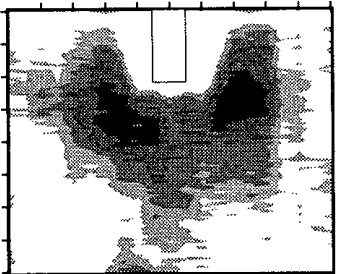

(f) No.6 $(n=9)$

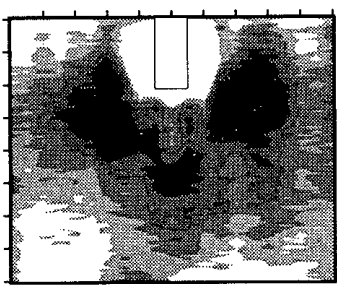

(i) No.9 $(n=13)$

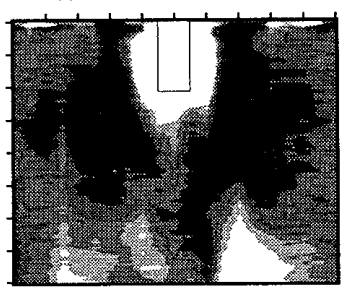

(1) No.12 $(n=20)$

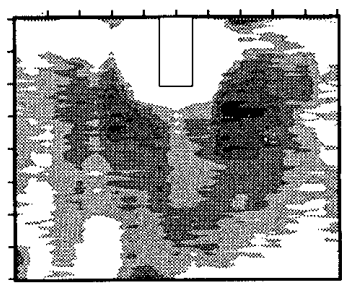

(o) No.15
重鍾落下

落下高さ:G.L. $+25 \mathrm{~cm}$

\section{重鍾落下}

落下高さ:孔底 $+25 \mathrm{~cm}$

平板載荷

図-18 $I_{\mathrm{dqc}}$ の分布図 
重鍾底面中心から半球状であることがわかる. なお，重 鍾および平板の底面周辺には $q_{\mathrm{c}}$ の增大がみられないが， この原因としては，重錘あるいは平板を取り除いた際に ゆるみが生じた可能性があること，重鍾あるいは平板の 貫入量（沈下量）に相当する土被りがなくなっている ことなどが考えられる。

図一 18 に基づいて，重錘の貫入の進行にともなう地 盤の締固め効果（締固めの範囲および程度）の推移を以 下に考察する．重鍾の貫入が1.5Dから2Dに進んだ場合 の締固め効果は, 落下高さが打撃孔底 $+25 \mathrm{~cm}$ の場合が
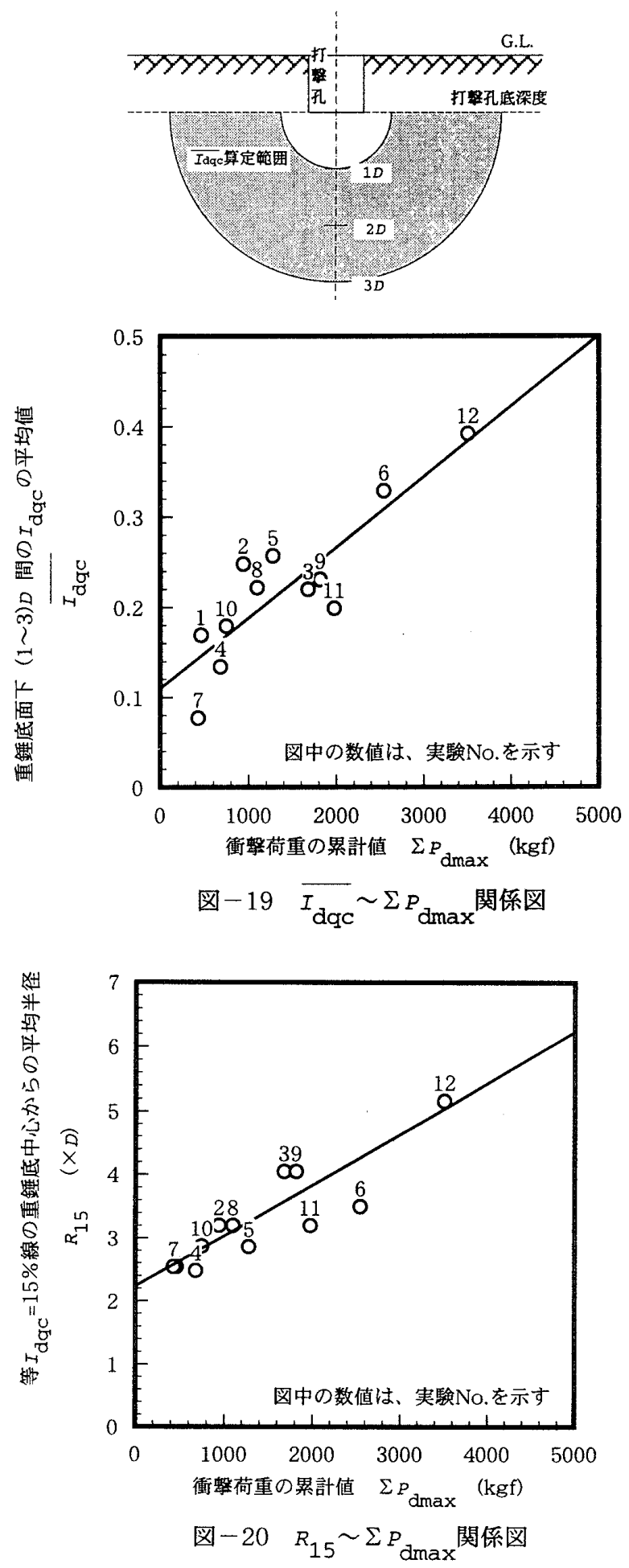

最も大きく, 次にG.L. $+25 \mathrm{~cm}$ の場合が大きい. 落下高さ が打撃孔底 $+50 \mathrm{~cm}$ および $G . L+50 \mathrm{~cm}$ の場合は，明瞭な 締固め効果の増大は現れていない。重錘が $1.5 D$ から $2 D$ まで貫入するのに必要な打撃回数 $n$ は，落下高さが打撃 孔底 $+50 \mathrm{~cm}$ およびG.L $+50 \mathrm{~cm}$ の場合で 3 回, 落下高さ がG. $L+25 \mathrm{~cm}$ の場合で 5 回, 打撃孔底+ $25 \mathrm{~cm}$ の場合で 7 回であって, 締固め効果の大小関係と整合している. なお，平板載荷試験の場合は，根入れ長の増加による締 固め効果の增大はほとんど現れておらず，ほぼ同等と みなせる。

一方，重鍾の貫入が1Dから1.5Dに進んだ場合の締固 め効果は, 打撃孔底 $+25 \mathrm{~cm}$ の場合が最も小さく, 他の 落下高さの場合はほぼ同等とみれる，重鍾が1Dから $1.5 D$ まで貫入するのに必要なnは, 落下高さが打撃孔底 $+50 \mathrm{~cm}$ おびG. $L+25 \mathrm{~cm}$ の場合で 3 回, G. $L+50 \mathrm{~cm}$ の 場合で 2 回, 打擊孔底 $+25 \mathrm{~cm}$ の場合で 7 回であって, 締固め効果の大小関係との整合性は認められない。しか し図ー14に示した衝撃荷重の最大值に着目すると, 落 下高さがG.L.+ $25 \mathrm{~cm}$ の場合が最も小さく, 他の落下高さ の場合はほぼ同等であり，締固め効果の大小関係と整合 している.なお, 平板載荷試験の場合は, 比較的大き な締固め効果が現れている.

以上のことから，重鍾の落下による締固め効果は，衝 撃荷重の最大値 $P_{\text {a } \max }$ と打撃回数nの $2 つ$ の因子に支配 されると考え, 各打撃時の $P_{\mathrm{amax}}$ の累計值 $\Sigma P_{\mathrm{d} \max }$ を求 めて締固め効果との関係を検討する. 締固め範囲の分布 が重錘底中心から半球状であることを考慮し，締固め程 度を現す量としては重鍾底中心から（1３）D間の $q_{c}$ の 增大率 $I_{\mathrm{dqc}}$ の平均値 $I_{\mathrm{aqc}}$ （後出の図-19参照）を, 締 固め範囲としては等 $I_{\mathrm{aqc}}=15 \%$ 線の重錘底中心からの平 均半径 $R_{15}$ を採用することとした. $I_{\mathrm{dqc}} \sim \sum P_{\mathrm{dmax}}$ 関係 を図一19に， $R_{15} \sim \sum P_{\mathrm{amax}}$ 関係を図一20に示す. 両図 とも，バラツキはあるが比較的高い相関性が認められ， 締固め効果は $\Sigma P_{\mathrm{dmax}}$ で推定できると考えられる.

\section{6. 結語}

本論文では，ゆるい砂地盤における重銛落下締固め工 法に関する室内模型実験の結果を報告し，衝撃荷重〜貫 入量関係の特性，衝擊荷重之静的支持力との関係およ び締固め効果について検討を加えた.これらの検討結果 をまとめると, 以下のとおりである.

1) 衝撃荷重〜貫入量曲線には，地盤のゆりこみ沈 下の特性が現れている。この特性は，重鍾の 1 打揧あた りの打撃エネルギーの影響は受けず，地盤の種類およ び状態（密度，含水比など）により一義的に決まると考 えられる。 
2）地表面における 1 打撃目の衝撃荷重の最大值は, 重鍾の衝突速度と原点を通る比例関係にある. しかし， 打撃を繰り返した場合には，衝撃荷重の最大值と重鍾 の衝突速度とは比例せず，同一衝突速度で繰り返し打撃 した場合でも衝撃荷重の最大值は次第に增大する.

3）重鍾落下による衝撃荷重の最大値と静的支持力 との大小関倸は，貫入量によって異なる．重鍾落下によ り生じた打撃孔底（深さ $1 D ， D$ : 重錘および平板の直径） における平板載荷試験の結果からは，衝撃荷重の最大値 は静的載荷における履歴最大荷重に相当すると考元られ た.

4）重錘落下による締固め効果（締固めの範囲およ び程度）は，衝撃荷重の最大值および打撃回数によって

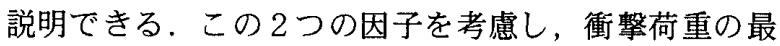
大值の累計值を求めて締固め効果と比較した結果, 両者 の間には比較的高い相関性が認められた。

\section{謝辞}

本実験を行うにあたり，多大のご協力を頂いた平成 6 年度の関西大学卒業研究生の下山尚毅, 林圭一, 藤裏和 弘および水谷毅の諸氏に感謝の意を表します。

\section{参考文献}

1)下平祐司，山局邦男，森国夫：重落下締固め工法の現場 実験結果ならびに地盤内最大応力分布の推定，日本建築学 会構造系論文集，第461号，pp.55～64，1994年7月

2)大島昭彦，高田直俊：重錘落下締固めにおける地盤への重 鍾貫入と衝搫力, 土木学会諭文集, No.487/」-26, pp.61 $\sim 67,1994.3$

3)山肩邦男，伊藤淳志，下平祐司，無津呂大輔：重鉷落下締 固め工法に関する室内模型実験 (その 1 : 実験概要)，第29回 土質工学研究発表会, pp.2063 2064, 平成6年6月

4)山局邦男, 伊藤淳志, 下平祐司, 無津呂大輔：重鉷落下締 固め工法に関する室内模型実験(その2：実験結果および考 察), 第29回土質工学研究発表会, pp.2065 2066, 平成 6 年6 月

5)山眉邦男，伊藤淳志，下平祐司，無津呂大輔：重鏵落下楴 固め工法に関する室内模型実験 (その 3 : 重鍾落下高さの影 響)，第30回土質工学研究発表会, pp.2043 2046, 平成7年7 月

6)大島昭彦，高田值俊，福本彦吉：地盤を重鍾打撃するとき の重鏵挙動の測定 - 打撃条件之地盤条件の影響 -, 第 29回土 質工学研究発表会，pp.2057～2060，平成6年6月

7)山崎康弘, 大島昭彦, 高田直倰, 池田通陽, 鳴海淔信 : 重 鏵落下による衝撃加速度の現場測定実験（第 1 報），第30 回土質工学研究発表会, pp.2035 2038, 平成7年7月

8)大島昭彦, 高田直俊, 山崎康弘, 池田通陽, 鳴海直信 : 重 鏵落下による衝撃加速度の現場測定実験（第 2 報），第30 回土質工学研究発表会, pp.2039 2042, 平成7年7月

9 )伊藤淳志, 山眉邦男 : 枠基礎の模型実験結果ならびに枠内 土の挙動に関する考察，日本建築学会構造系論文報告集， 第409号, pp.123〜132,1990年3月

10)高田直俊, 大島昭彦, 池田通陽，竹内功：重鍾落下締固め 工法の遠心模型実験－重錘貫入量と地盤変形 - , 土木学会 論文集，No.475/」 -24,pp.89〜97, 1993.9 